\title{
Review
}

\section{Functional implications of axon initial segment cytoskeletal disruption in stroke}

\author{
Ohad STOLER, Ilya A FLEIDERVISH*
}

Department of Physiology and Cell Biology, Faculty of Health Sciences, Ben-Gurion University of the Negev, Beer Sheva 84105, Israel

\begin{abstract}
Axon initial segment (AIS) is the proximal part of the axon, which is not covered with a myelin sheath and possesses a distinctive, specialized assembly of voltage-gated ion channels and associated proteins. AlS plays critical roles in synaptic integration and action potential generation in central neurons. Recent evidence shows that stroke causes rapid, irreversible calpain-mediated proteolysis of the AIS cytoskeleton of neurons surrounding the ischemic necrotic core. A better understanding of the molecular mechanisms underlying this "non-lethal" neuronal damage might provide new therapeutic strategies for improving stroke outcome. Here, we present a brief overview of the structure and function of the AIS. We then discuss possible mechanisms underlying stroke-induced AIS damage, including the roles of calpains and possible sources of $\mathrm{Ca}^{2+}$ ions, which are necessary for the activation of calpains. Finally, we discuss the potential functional implications of the loss of the AIS cytoskeleton and ion channel clusters for neuronal excitability.
\end{abstract}

Keywords: axon initial segment; stroke; $\mathrm{Ca}^{2+}$; calpain; spreading depression; sodium channels

Acta Pharmacologica Sinica (2016) 37: 75-81; doi: 10.1038/aps.2015.107; published online 21 Dec 2015

\section{Introduction}

Stroke is the fourth most common cause of death and the leading cause of disability in adults ${ }^{[1]}$. Stroke-associated neurological abnormalities partly depend on neuronal loss in the primary damage area. It is widely recognized that aberrant neuronal circuit function in regions surrounding the stroke necrotic core could be responsible for the development of post-stroke neurological deficits, seizures, and psychiatric and cognitive disabilities ${ }^{[2]}$. Whereas most research over the past decade has focused on dendritic dysfunction as a consequence of ischemic stroke, recent morphological evidence indicates that stroke causes rapid, irreversible calpain-mediated proteolysis of the AIS cytoskeleton of neurons on the periphery of ischemic territory ${ }^{[3]}$. The AIS, an approximately $40-$ to $60-\mu \mathrm{m}$-long segment devoid of myelin and adjacent to the cell body ${ }^{[4]}$, represents a highly specialized structure ${ }^{[5-8]}$ that plays critical roles in synaptic integration and action potential (AP) generation. Under most conditions, central neurons are strongly biased to initiate AP in the AIS ${ }^{[9]}$ rather than in the nodes of Ranvier ${ }^{[10]}$ or in the dendrites ${ }^{[11]}$. Excitable properties of the AIS are largely determined by its electrotonic interactions with the somatodendritic compartment ${ }^{[12-14]}$ and by distinctive patterns of density and characteristics of voltage-gated

\footnotetext{
* To whom correspondence should be addressed. E-mail ilya@bgu.ac.il

Received 2015-09-17 Accepted 2015-10-28
}

ion channels. These active and passive parameters appear to be highly plastic under physiological conditions ${ }^{[6,15-17]}$. The focus of this review is to summarize the recent findings on the mechanisms of stroke-induced AIS disruptions and to discuss their implications for AIS ion channel function and for neuronal excitability.

\section{AIS structure}

Early morphological studies defined AIS as the proximal part of the axon where the neuronal membrane is not covered with a myelin sheath. Many recent studies, however, redefine AIS as the proximal portion of the axon which possesses a distinctive, specialized assembly of cytoskeletal and scaffold proteins ${ }^{[18]}$. The main scaffold protein that is responsible for the anchoring of ion channels in the AIS is Ankyrin G (AnkG) ${ }^{[19]}$. The loss of AnkG causes disassembly of the AIS structure ${ }^{[20]}$. AnkG has a molecular mass of $480 \mathrm{kDa}$ and is composed of a membrane-binding domain, a spectrin-binding domain, a serine-rich domain, a long tail (2200 amino acids) and a carboxyterminal domain. In comparison to AnkG $480 \mathrm{kDa}$, the second longest isoform of AnkG found at the AIS, AnkG $270 \mathrm{kDa}$, lacks the last 1900 amino-acids of the tail ${ }^{[21]}$. AnkG is one of the earliest proteins to take part in the formation of the AIS ${ }^{[22]}$. The mechanism of AnkG clustering is not fully understood. Several studies have concluded that an important regulator of the transcription factor NF-KB, IkBa, is also present at the early stages of AIS assembly ${ }^{[23]}$. The phosphorylation of IkBa by the 
IKK complex releases NF- $\mathrm{KB}$. Interference in this sequence could cause damage to AnkG clustering. Another mechanism associated with AnkG clustering within the AIS is the absence of AnkB, aII-spectrin, or $\beta I I-s p e c t r i n{ }^{[24]}$. These proteins appear in developing axons prior to AnkG and spread from the distal part of the axon towards the proximal part. AnkG begins to accumulate in the proximal part of the axon, a segment where AnkB, aII-spectrin and $\beta I I-s p e c t r i n$ are absent. AnkG is also attached to microtubules through EB1/EB3 ${ }^{[25]}$. This stabilizes the AIS and perhaps also regulates vesicular transport ${ }^{[26]}$.

Another important scaffold protein found in the AIS is $\beta I V-$ spectrin $^{[27]}$. $\beta I V$-spectrin binds to AnkG and is considered essential to maintaining the proper organization of the AIS, but not to its development. The $\beta I V$-spectrin $\Sigma 6$ isoform is the main isoform found in the AIS, although it lacks the actinbinding domain ${ }^{[19]}$. A recent study using super-resolution fluorescence microscopy revealed the structure of the axon cytoskeleton $^{[28]}$. Circumference ring-like structures composed of actin were found to repeat every $\sim 180 \mathrm{~nm}$. Spectrin is formed of a hetero-tetrameric complex of two aII-spectrins and two $\beta$ II-spectrins, with the $\beta$-spectrins bound to the actin/adducin filaments ${ }^{[28,29]}$. A study by $\mathrm{Xu}$ et $a l^{[28]}$ revealed that both the $\beta$-spectrins that are present in the axon and the $\beta I V$-spectrin that is present in the AIS form the same repetitive periodic structures at intervals of $\sim 180 \mathrm{~nm}$.

NrCAM and NF186 are adhesion molecules that appear in the late stages of AIS assembly ${ }^{[18]}$. They bind to AnkG through their FIGQY tyrosine domain when the domain is not phosphorylated ${ }^{[30]}$. NF186 has an important role in the formation of GABAergic synapses with axo-axonal Chandelier cells $^{[31]}$. The AIS GABAergic synapses are believed to be inhibitory, although there is evidence of their surprising excitatory effect ${ }^{[32]}$. NrCAM and NF186 also play a critical role in the function of AIS as a "diffusion barrier", for maintaining neuronal polarity ${ }^{[26]}$. AnkG can also bind to GABAa receptorassociated protein (GABARAP) and stabilize the GABAergic synapses $^{[33]}$.

\section{Ion channels}

\section{$\mathrm{Ca}^{2+}$ channels}

The presence of calcium channels in the AIS membrane has been appreciated for the past 20 years ${ }^{[34,35]}$, but only in recent years has their function begun to receive attention. Using twophoton fluorescence imaging, electrical recording and pharmacological tools, Bender and Trussell ${ }^{[36]}$ found that the AISs of dorsal cochlear nucleus cartwheel interneurons contain Tand R-type voltage-gated $\mathrm{Ca}^{2+}$ channels. They also demonstrated that blockade of the $\mathrm{Ca}^{2+}$ channels delays spike generation and causes the AP voltage threshold to rise. In a different study, Bender and Trussell found that dopamine released from dopaminergic synapses can reduce calcium influx to the AIS by $\sim 30 \%$ via activation of G-protein coupled dopamine type 3 receptors ${ }^{[37]}$. AIS of L5 pyramidal neurons of the ferret prefrontal cortex were shown to contain a different set of $\mathrm{Ca}^{2+}$ channels, $\mathrm{P} / \mathrm{Q}$ and $\mathrm{N}^{[38]}$, which respond to both sub- and supra-threshold depolarization.

\section{$\mathrm{K}^{+}$channels}

$\mathrm{K}_{\mathrm{v}}$ 7.2- and $\mathrm{K}_{\mathrm{v}}$ 7.3-containing channels present in the AIS and nodes of Ranvier generate slowly activating, non-inactivating $M$ current that is active at a near-threshold range of voltages $^{[39]}$. The channels bind to AnkG at the same motif as voltage-gated $\mathrm{Na}^{+}$channels. The central axons also contain $\mathrm{K}_{\mathrm{v}} 1.1$ and 1.2 channels whose localization mechanism does not depend on AnkG binding, but rather on PSD-93 and Caspr $2^{[40]}$, which are present in the juxtaparanodes ${ }^{[41]}$. When both $\mathrm{K}_{\mathrm{v}} 1.1$ and 1.2 channels are present in the AIS of a cell, they show similar patterns of distribution along the $\mathrm{AIS}^{[42]}$. Thus, the density of these channels in L2/3 and CA1 pyramidal neurons gradually increases towards the distal part of the AIS, whereas in the AIS of L5 and CA3 pyramidal neurons, the channels are evenly distributed ${ }^{[42]}$. The $\mathrm{K}_{\mathrm{v}} 1.1$ and 1.2 channels give rise to rapidly activating, low-threshold, slowly inactivating, outward potassium current ${ }^{[43,44]}$. A subthreshold depolarization can inactivate a portion of these channels and cause a significant broadening of the axonal APs which, in turn, enhances the AP elicited $\mathrm{Ca}^{2+}$ influx in the proximal axonal terminals thereby increasing the probability of synaptic release ${ }^{[45,46]} \cdot \mathrm{K}_{\mathrm{v}} 2.2$ and $\mathrm{K}_{\mathrm{v}} 3$ found in principal cells of the medial nucleus of the trapezoid body are considered to have a role in the regulation of inter-spike intervals during repetitive firing ${ }^{[47]}$. The presence of $\mathrm{Ca}^{2+}$-activated BK channels in the paranodes of cerebellar Purkinje cells has been recently reported ${ }^{[48]}$. These channels are characterized by rapid activation and deactivation kinetics and by allosteric gating that depend on the local intracellular $\mathrm{Ca}^{2+}$ concentration.

\section{$\mathrm{Na}^{+}$channels}

The functionally critical features of AIS excitability are largely determined by the density patterns and characteristics of voltage-gated $\mathrm{Na}^{+}\left(\mathrm{Na}_{\mathrm{v}}\right)$ channels. $\mathrm{Na}_{\mathrm{v}}$ channel density is relatively high in the proximal axon and in the nodes of Ranvier in both excitatory and inhibitory neurons. There remains some controversy, however, as to what extent the density of functional $\mathrm{Na}^{+}$channels is greater in the AIS than in the soma ${ }^{[10,49-52]}$. Within the AIS and in the nodes, these channels are anchored to AnkG by the binding motif in the II/III loop of the a subunit ${ }^{[53]}$. In other areas of the cell, the $\mathrm{Na}_{\mathrm{v}}$ channels are prone to elimination by endocytosis ${ }^{[54]}$. Phosphorylation of the $\mathrm{Na}_{\mathrm{v}}$ binding motif of AnkG by protein kinase CK2 (an enzyme located specifically in the AIS) regulates the interaction between these two important proteins ${ }^{[55]}$.

The $\mathrm{Na}^{+}$channel is composed of large, pore-forming a subunits and four smaller auxiliary $\beta$ subunits ${ }^{[56]}$. Four of the $a$ subunits (encoded by SCN1A-SCN3A and SCN8A) are considered to be responsible for the $\mathrm{Na}_{\mathrm{v}} 1.1-\mathrm{Na}_{\mathrm{v}} 1.3$ and $\mathrm{Na}_{\mathrm{v}} 1.6$ channels in central neurons ${ }^{[57]}$. Auxiliary $\beta$-subunits in CNS are encoded by SCN1B-4B genes ${ }^{[57]}$. The AIS of central neurons contain a mixture of these subtypes ${ }^{[42]}$, and in most neurons, they are not evenly distributed along the AIS. This causes great diversity in AIS sodium current among different neurons ${ }^{[58]}$. In addition, this can play a role in the difference in AP initiation in different neuronal types, along with the unique 
cable properties of the $\mathrm{AIS}^{[12]}$. In most neurons, the main $\mathrm{Na}_{\mathrm{v}}$ channel in the AIS and nodes of Ranvier is $\mathrm{Na}_{\mathrm{v}} 1.6$, and it is present in all the major neuron types of the neocortex, hippocampus, cerebellum and olfactory bulb ${ }^{[42]}$. In L5 cortical and in CA2/3 hippocampal pyramidal neurons, $\mathrm{Na}_{\mathrm{v}} 1.2$ channels are present in the proximal part of the AIS while $\mathrm{Na}_{\mathrm{v}} 1.6$ channels almost exclusively populate the distal part of the $\operatorname{AIS}^{[42,51,59]}$. Other study suggests, however, that the distribution of $\mathrm{Na}_{\mathrm{v}} 1.6$ within the AIS is more uniform ${ }^{[42]}$. $\mathrm{Na}_{\mathrm{v}} 1.1$ channels are found in the proximal part of the AIS of the parvalbumin (PV)- and somatostatin (SST)-positive GABAergic interneurons ${ }^{[60]}$ of the neocortex and cerebellum ${ }^{[42]}$, in retinal ganglion cells ${ }^{[61]}$ and in spinal cord motor neurons ${ }^{[62]}$. Mutations in the genes encoding the $\mathrm{Na}_{\mathrm{v}} 1.1$ channels can cause Dravet syndrome and other types of infantile epilepsy ${ }^{[63]}$. In both PV and SST interneurons, $\mathrm{Na}_{\mathrm{v}} 1.6$ channels were found in the distal part of the AIS, whereas $\mathrm{Na}_{\mathrm{v}} 1.2$ channels were found in the proximal part of the AIS only in SST-positive INs ${ }^{[60]}$. A recent study showed that, in human cortical pyramidal cells, the pattern of $\mathrm{Na}^{+}$channel distribution is similar to that in rodents ${ }^{[64]}$. The primary difference was a clustering of $\mathrm{Na}_{\mathrm{v}} 1.2$ channel in some nodes of Ranvier in addition to the $\mathrm{Na}_{\mathrm{v}} 1.6$ channels.

$\mathrm{Na}_{\mathrm{v}}$ channels generate three functionally different currents: (1) $I_{\mathrm{NaT}}$, transient $\mathrm{Na}^{+}$current responsible for the AP upstroke generation; (2) $\mathrm{I}_{\mathrm{NaP}}$, non-inactivating, persistent $\mathrm{Na}^{+}$current, that is generated predominately in the proximal part of the axon $^{[65]}$ and plays a role in the amplification of PSPs ${ }^{[66]}$, repetitive firing ${ }^{[67]}$ and in bursts generation ${ }^{[68]}$; and (3) $\mathrm{I}_{\mathrm{NaR}}$, resurgent $\mathrm{Na}^{+}$current that in some neurons facilitates generation of repetitive $\mathrm{APs}^{[69]}$.

\section{AIS plasticity}

Recent studies $^{[16,70]}$ (for review see ${ }^{[6,15]}$ ) revealed that the AIS of central neurons is more dynamic than previously thought. Thus, chronic increase in the firing rate of cultured hippocampal neurons result in AIS relocation away from soma ${ }^{[16]}$, while chronic sensory deprivation causes AIS elongation in the chick auditory brainstem ${ }^{[70]}$. Similar to previously described forms of long-term plasticity of intrinsic excitability ${ }^{[71]}$, it was reported that the plastic changes in the AIS require cytoplasmic $\mathrm{Ca}^{2+}$ elevation ${ }^{[72]}$. AIS plasticity was proposed to be bidirectional and homeostatic ${ }^{[17]}$. The mechanism of AIS plasticity is not fully understood. Most likely, it is related to changes in the intra-axonal boundaries between AnkG and $A n k B^{[24]}$. AnkG overexpression has been shown to increase AIS length in cultured hippocampal neurons, whereas AnkB overexpression causes the opposite. The activity-dependent relocation of the AIS in dissociated hippocampal neurons ${ }^{[16]}$ requires L-type channel-mediated $\mathrm{Ca}^{2+}$ influx and calcium-sensitive phosphatase calcineurin activation ${ }^{[72]}$. The functional consequences of AIS plasticity for neuronal excitability are not completely clear. They have to be viewed in a framework of more general biophysical model of AP initiation incorporating the details of $\mathrm{Na}^{+}$channel distribution, characteristics and electronic interactions between the trigger zone and neighboring compartments $^{[12]}$. Interestingly, AIS plasticity has also been found in models of stroke, demyelination, epilepsy, Angelman syndrome, etc. (for review see ${ }^{[73]}$ ). Some of these disease-related forms of AIS plasticity will be discussed in the following sections.

\section{AIS damage in stroke}

Using immunohistochemistry and immunoblot analysis in a rat MCA occlusion model of stroke, Schafer et al (2009) ${ }^{[3]}$ found that stroke, 3-72 $\mathrm{h}$ from induction, causes massive damage to the AIS, including proteolysis of AnkG and $\beta I V$-spectrin. In addition, proteolysis of aII-spectrin in the distal part of the axon was observed. There was also proteolysis of $\mathrm{Na}_{\mathrm{v}}$ channels but only $12 \mathrm{~h}$ after stroke and on smaller scale. The proteolysis of scaffold proteins was assumed to be caused by $\mathrm{Ca}^{2+}$ dependent cysteine protease-calpain. In an in-vitro oxygen glucose deprivation (OGD) model, calpain inhibitors, but not the inhibitors of other proteases, reduced the damage to the AIS scaffold proteins. The researchers also showed that this process is not linked to cell death. Although the nodes of Ranvier have a similar structure to that of the AIS, surprisingly, they were not disrupted in this model. In a similar model of diffused axonal injury and axotomy, a significant local, $\mathrm{Ca}^{2+}$ dependent, calpain proteolysis of scaffold proteins, cytoskeleton ${ }^{[74]}$ and $\mathrm{Na}_{\mathrm{v}}$ channels ${ }^{[75]}$ was found. Interestingly, in addition to calpain inhibitors, proteolysis was also blocked by the $\mathrm{Na}^{+}$channel blocker TTX, suggesting a role for partially proteolyzed $\mathrm{Na}^{+}$channels in the axonal $\mathrm{Ca}^{2+}$ overload ${ }^{[76]}$. Longterm consequences of stroke on AIS structure was studied in cortical neurons two weeks after photo-thrombosis ${ }^{[7]}$. AIS length of L5 pyramidal neurons in the vicinity of the stroke necrotic core was shortened by $\sim 15 \%$ while the overall intensity of the immunofluorescence for AnkG and $\beta I V$-spectrin was not significantly different. These changes in AIS structure are, most likely, the result of functional remodeling of the peristroke neuronal circuits, rather than calpain-mediated AIS damage.

In all the above models, the damage to the AIS was mediated by calpain activation. Two subtypes of calpain, $\mu$-calpain (calpain I) and m-calpain (calpain II), are considered to be active during neuronal injury ${ }^{[78]}$. One of the main differences between the two calpain subtypes is that activation of m-calpain requires extremely high elevation in intracellular $\mathrm{Ca}^{2+}$ (400-800 $\mu \mathrm{mol} / \mathrm{L})$, while $\mu$-calpain is significantly activated when $\mathrm{Ca}^{2+}$ rises to $3-50 \mu \mathrm{mol} / \mathrm{L}^{[79]}$. Calpain also has a major role in degradation of other axonal cytoskeletal and scaffold proteins during ischemia such as microtubules, neurofilaments and aII-spectrin (reviewed in ${ }^{[80]}$ ). The source of the pathological $\mathrm{Ca}^{2+}$ elevation that would be sufficient to activate calpains is one of the most important aspects of the AIS damage mechanism.

\section{$\mathrm{Ca}^{2+}$ overload}

In the center of an ischemic territory, the countdown to neuronal death starts with the onset of anoxic depolarization, approximately 1-5 min after the onset of ischemia ${ }^{[81]}$, when the neuronal cation outflux by the ATP-dependent pumps fails 
to compensate for the cation influx of sodium and calcium ${ }^{[82]}$. Excessive release of glutamate begins a short time after the start of oxygen and glucose depravation $(<15 \mathrm{~s})^{[81]}$. In the postsynaptic membrane, the massive release of glutamate activates AMPA and NMDA receptors ${ }^{[83,84]}$. Influx of $\mathrm{Na}^{+}$and $\mathrm{Ca}^{2+}$ ions via the glutamate receptors causes depolarization and activates $\mathrm{Ca}^{2+}$ signaling mechanisms. AMPA receptors are usually impermeable to $\mathrm{Ca}^{2+}$ because of the presence of the GluR2 subunit ${ }^{[85]}$. Under ischemic conditions, there is an increase in AMPA-mediated $\mathrm{Ca}^{2+}$ flux through GluR2-lacking AMPA receptors ${ }^{[86]}$.

Another plausible source of $\mathrm{Ca}^{2+}$ in stroke is influx via the channels belonging to the Transient Receptor Potential (TRP) family, in particular the TRPM2 and TRPM7 channels ${ }^{[87,88]}$. TRPM2 channels are thought to be activated by reactive oxygen species (ROS), nitric oxide (NO), and ADP-ribose (ADPR) ${ }^{[89]}$. TRPM7 channels can be activated through low extracellular divalent cations, ROS, and $\mathrm{pH}$ changes ${ }^{[64]}$. All of the above are present in neuronal injury areas. TRPM2 is a cation, nonselective ion channel that is permeable to $\mathrm{Ca}^{2+}, \mathrm{Na}^{+}$and $\mathrm{K}^{+}$ ions. TRPM7 is characterized by high permeability to divalent cations such as $\mathrm{Ca}^{2+}, \mathrm{Mg}^{2+}$ and $\mathrm{Zn}^{2+[90]}$. Down regulation of TRPM7 in hippocampal CA1 neurons lowered the $\mathrm{Ca}^{2+}$ current through TRPM7 channels and prevented delayed neuronal death $^{[91]}$.

In the last decade, several studies have implicated members of recently discovered Pannexin channel subfamily in neuronal injury and death ${ }^{[92]}$. Pannexins are non-selective, largepore channels ${ }^{[93]}$. The first study that investigated Pannexin 1 channels in an OGD model found them passing a large inward current after $10 \mathrm{~min}$ of $\mathrm{OGD}^{[94]}$. Their activation is likely due to $\mathrm{NO}$ and $\mathrm{ROS}^{[95]}$. An increase in Pannexin 1 open probability was attributed to NMDA receptor activation. Namely, activation of Src family kinases (SFKs) by NMDA receptors causes phosphorylation of Pannexin 1 resulting in its activation ${ }^{[96]}$. It is still unclear, however, to what extent Pannexin activation contributes to neuronal injury in in vivo stroke. One study using a MCA occlusion model showed that down-regulation of Pannexin 1 and 2 causes a significant decrease in infarct volume $^{[97]}$. Another study using an anoxic model in hippocampal slices, however, found no effect of pharmacological blockade of Pannexins on the development of anoxic depolarization. Moreover, the anoxic depolarization was completely abolished by bath application of glutamate and GABA receptor blockers $^{[98]}$.

There are also other channels and exchangers that are considered to be activated during ischemia and are permeable to $\mathrm{Ca}^{2+}$ such as L-type $\mathrm{Ca}^{2+}$ channels, acid-sensing ion channels (ASICs), $\mathrm{Na}^{+} / \mathrm{Ca}^{2+}$ exchangers (NCX) and P2X7 channels ${ }^{[99]}$ sensitive to extracellular ATP concentrations (reviewed in $\operatorname{Ref}^{[100]}$ ). P2X7 channels are considered to be activated in neuronal injury due to high extracellular concentrations of ATP and its metabolites under ischemic conditions ${ }^{[99]}$, but the activation is not sufficient to cause neuronal death alone ${ }^{[101]}$. A recently published study found that $\mathrm{P} 2 \mathrm{X} 7$ receptor activation reduced the density of AnkG and $\mathrm{Na}_{\mathrm{v}}$ channels in the AIS, whereas inhibition of these receptors resulted in the opposite ${ }^{[102]}$. Interestingly, in a MCA occlusion model similar to that in Schafer et $a l^{[3]}$, inhibition of $\mathrm{P} 2 \mathrm{X} 7$ receptors prevented the AIS disruption.

In summary, all the above mechanisms may play a role in AIS $\mathrm{Ca}^{2+}$ elevation during ischemia. It remains to be studied, however, whether $\mathrm{Ca}^{2+}$ elevation in the proximal axon is due to direct influx, whether the relevant channels and transporters are localized in the AIS, whether intracellular $\mathrm{Ca}^{2+}$ stores are involved, or whether it reflects lateral $\mathrm{Ca}^{2+}$ diffusion from the soma.

\section{Peri-infarct depolarization}

Whereas terminal depolarization in the ischemic core is associated with neuronal death ${ }^{[82]}$, recent studies revealed the existence of persistent waves of transient depolarization spreading in the peri-infarction, penumbra areas ${ }^{[2]}$. These waves spread at velocity of 2-6 $\mathrm{mm}$ per minute causing significant $\mathrm{Ca}^{2+}$ and $\mathrm{Na}^{+}$elevations, loss of excitability, neuronal swelling, an increase in the interstitial $\mathrm{K}^{+}$concentration, dendritic damage and massive release of excitatory neurotransmitters such as glutamate $^{[2]}$. Spreading depolarization, on one hand increases the tissue's metabolic demand and on the other hand could decrease the blood supply due to "inverse" neurovascular coupling ${ }^{[103]}$. The mismatch between the metabolic demand and supply could contribute to the expansion of the damage to the tissues that did not suffer from direct ischemia and thus cause the stroke to grow in the first hour following the cerebrovascular event ${ }^{[104]}$. The damage to penumbra could be reversible (in the first six hour) and the long-term outcome of the stroke can be dramatically improved with the fast revascularization of penumbra ${ }^{[105]}$. A recent study demonstrated that somatosensory activation of the cortex, apparently by increasing the metabolic demand in the penumbra, could trigger spreading depolarization waves in penumbral "hot zones" ${ }^{[106]}$. The mechanisms of spreading depolarization wave generation remain unclear.

\section{Functional implications}

Evidence by Schafer et $a l^{[3]}$ in a rodent MCA occlusion model indicates that stroke causes a massive degradation of scaffold proteins of the AIS, but not of the nodes of Ranvier. Interestingly, the degradation of scaffold proteins was not associated with a massive immediate degradation of the $\mathrm{Na}_{\mathrm{v}}$ channels. As discussed in the first section, $\mathrm{Na}_{\mathrm{v}}$ channel anchoring and assembly is AnkG-dependent ${ }^{[20]}$. What are the possible functional consequences of the AIS proteolysis? The fate of the AIS $\mathrm{Na}_{\mathrm{v}}$ channels remains uncertain. One possibility is that the channels undergo proteolysis and become non-functional, as described in the traumatic brain injury model ${ }^{[75]}$. It is noteworthy that distinctive $\mathrm{Na}^{+}$channel a-subunits have different susceptibility to calpain cleavage, raising a possibility that the extent of channel proteolysis may vary over the AIS length reflective of the nonhomogeneous channels distribution. Moreover, if indeed the main source of the AIS $\mathrm{Ca}^{2+}$ elevation is by diffusion from the soma, there might be a 
$\mathrm{Ca}^{2+}$ and proteolysis gradient over the AIS length, similar to that in the axotomy model ${ }^{[7]}$. Because the AP trigger zone is located in the distal part of the AIS ${ }^{[11,12,44]}$, detailed knowledge of the extent of the proteolysis at this location is necessary for understanding the effect of stroke on neuronal excitability. The middle AIS section might contribute to AP generation by decreasing the capacitive load on the trigger zone. It also plays a critical role in AP backpropagation by providing current, which starts the regenerative depolarization wave in the soma and dendrites ${ }^{[12]}$. Damage to the channels in the middle part of the AIS, therefore, can increase the AP threshold and suppress the AP backpropagation and spike timing dependent plasticity (STDP). Destruction of the entire AIS, especially the distal part, could make neurons in the stroke penumbra less responsive to synaptic input and thus be partially responsible for the circuit dysfunction and neurological deficits in stroke.

Another possibility is that following cleavage, the channels remain functional while detached from the scaffold. Detached $\mathrm{Na}^{+}$channels are expected to diffuse laterally in the membrane and accumulate either in the soma or in the nodes of Ranvier where the scaffold is intact. The presence of partially proteolyzed $\mathrm{Na}^{+}$channels in the nodes might significantly affect their excitable properties, especially if proteolysis led to modification of channel gating ${ }^{[76]}$.

In summary, understanding the functional consequences of AIS damage in the stroke penumbra may help to identify potential pharmacological targets for preventing secondary neuronal damage and limiting stroke complications.

\section{References}

1 Mozaffarian D, Benjamin EJ, Go AS, Arnett DK, Blaha MJ, Cushman $\mathrm{M}$, et al. Heart disease and stroke statistics--2015 update: a report from the American Heart Association. Circulation 2015; 131: e29322.

2 Dreier JP. The role of spreading depression, spreading depolarization and spreading ischemia in neurological disease. Nat Med 2011; 17: 439-47.

3 Schafer DP, Jha S, Liu F, Akella T, McCullough LD, Rasband MN. Disruption of the axon initial segment cytoskeleton is a new mechanism for neuronal injury. J Neurosci 2009; 29: 13242-54.

4 Tomassy GS, Berger DR, Chen HH, Kasthuri N, Hayworth KJ, Vercelli A, et al. Distinct profiles of myelin distribution along single axons of pyramidal neurons in the neocortex. Science 2014; 344: 319-24.

5 Kole MH, Stuart GJ. Signal processing in the axon initial segment. Neuron 2012; 73: 235-47.

6 Grubb MS, Shu Y, Kuba H, Rasband MN, Wimmer VC, Bender KJ. Short- and long-term plasticity at the axon initial segment. J Neurosci 2011; 31: 16049-55.

7 Bender KJ, Trussell LO. The physiology of the axon initial segment. Annu Rev Neurosci 2012; 35: 249-65.

8 Bean BP. The action potential in mammalian central neurons. Nat Rev Neurosci 2007; 8: 451-65.

9 Palmer LM, Stuart GJ. Site of action potential initiation in layer 5 pyramidal neurons. J Neurosci 2006; 26: 1854-63.

10 Kole MH, Ilschner SU, Kampa BM, Williams SR, Ruben PC, Stuart GJ. Action potential generation requires a high sodium channel density in the axon initial segment. Nat Neurosci 2008; 11: 178-86.
11 Stuart G, Schiller J, Sakmann B. Action potential initiation and propagation in rat neocortical pyramidal neurons. J Physiol 1997; 505: 617-32.

12 Baranauskas G, David Y, Fleidervish IA. Spatial mismatch between the $\mathrm{Na}^{+}$flux and spike initiation in axon initial segment. Proc Natl Acad Sci U S A 2013; 110: 4051-6.

13 Eyal G, Mansvelder HD, de Kock CP, Segev I. Dendrites impact the encoding capabilities of the axon. J Neurosci 2014; 34: 8063-71.

14 Brette R. Sharpness of spike initiation in neurons explained by compartmentalization. PLoS Comput Biol 2013; 9: e1003338.

15 Adachi R, Yamada R, Kuba H. Plasticity of the axonal trigger zone. Neuroscientist 2015; 21: 255-65.

16 Grubb MS, Burrone J. Activity-dependent relocation of the axon initial segment fine-tunes neuronal excitability. Nature 2010; 465: 1070-4.

17 Gründemann J, Häusser M. Neuroscience: A plastic axonal hotspot. Nature 2010; 465: 1022-3.

18 Grubb MS, Burrone J. Building and maintaining the axon initial segment. Curr Opin Neurobiol 2010; 20: 481-8.

19 Yoshimura T, Rasband MN. Axon initial segments: diverse and dynamic neuronal compartments. Curr Opin Neurobiol 2014; 27: 96-102.

20 Hedstrom KL, Ogawa Y, Rasband MN. AnkyrinG is required for maintenance of the axon initial segment and neuronal polarity. J Cell Biol 2008; 183: 635-40.

21 Kordeli E, Lambert S, Bennett V. AnkyrinG. A new ankyrin gene with neural-specific isoforms localized at the axonal initial segment and node of Ranvier. J Biol Chem 1995; 270: 2352-9.

22 Jenkins SM, Bennett V. Ankyrin-G coordinates assembly of the spectrin-based membrane skeleton, voltage-gated sodium channels, and L1 CAMs at Purkinje neuron initial segments. J Cell Biol 2001; 155: 739-46.

23 Sanchez-Ponce D, Tapia M, Munoz A, Garrido JJ. New role of IKK alpha/beta phosphorylated I kappa B alpha in axon outgrowth and axon initial segment development. Mol Cell Neurosci 2008; 37 : 832-44.

24 Galiano MR, Jha S, Ho TS, Zhang C, Ogawa Y, Chang KJ, et al. A distal axonal cytoskeleton forms an intra-axonal boundary that controls axon initial segment assembly. Cell 2012; 149: 1125-39.

25 Leterrier C, Vacher H, Fache MP, d'Ortoli SA, Castets F, Autillo-Touati A, et al. End-binding proteins EB3 and EB1 link microtubules to ankyrin $G$ in the axon initial segment. Proc Natl Acad Sci U S A 2011; 108: 8826-31.

26 Rasband MN. The axon initial segment and the maintenance of neuronal polarity. Nat Rev Neurosci 2010; 11: 552-62.

27 Yang $\mathrm{Y}$, Ogawa $\mathrm{Y}$, Hedstrom KL, Rasband MN. betalV spectrin is recruited to axon initial segments and nodes of Ranvier by ankyrinG. J Cell Biol 2007; 176: 509-19.

28 Xu K, Zhong G, Zhuang X. Actin, spectrin, and associated proteins form a periodic cytoskeletal structure in axons. Science 2013; 339: 452-6.

29 Leterrier C, Dargent B. No Pasaran! Role of the axon initial segment in the regulation of protein transport and the maintenance of axonal identity. Semin Cell Dev Biol 2014; 27: 44-51.

30 Garver TD, Ren Q, Tuvia S, Bennett V. Tyrosine phosphorylation at a site highly conserved in the L1 family of cell adhesion molecules abolishes ankyrin binding and increases lateral mobility of neurofascin. J Cell Biol 1997; 137: 703-14.

31 Ango F, di Cristo G, Higashiyama H, Bennett V, Wu P, Huang ZJ. Ankyrin-based subcellular gradient of neurofascin, an immunoglobulin family protein, directs GABAergic innervation at 
purkinje axon initial segment. Cell 2004; 119: 257-72.

32 Szabadics J, Varga C, Molnar G, Olah S, Barzo P, Tamas G. Excitatory effect of GABAergic axo-axonic cells in cortical microcircuits. Science 2006; 311: 233-5.

33 Tseng WC, Jenkins PM, Tanaka M, Mooney R, Bennett V. Giant ankyrin-G stabilizes somatodendritic GABAergic synapses through opposing endocytosis of GABAA receptors. Proc Natl Acad Sci U S A 2015; 112: 1214-9.

34 Callewaert G, Eilers J, Konnerth A. Axonal calcium entry during fast 'sodium' action potentials in rat cerebellar Purkinje neurones. J Physiol 1996; 495: 641-7.

35 Lev-Ram V, Ellisman MH. Axonal activation-induced calcium transients in myelinating Schwann cells, sources, and mechanisms. J Neurosci 1995; 15: 2628-37.

36 Bender KJ, Trussell LO. Axon initial segment $\mathrm{Ca}^{2+}$ channels influence action potential generation and timing. Neuron 2009; 61: 259-71.

37 Bender KJ, Ford CP, Trussell LO. Dopaminergic modulation of axon initial segment calcium channels regulates action potential initiation. Neuron 2010; 68: 500-11.

38 Yu Y, Maureira C, Liu X, McCormick D. P/Q and N channels control baseline and spike-triggered calcium levels in neocortical axons and synaptic boutons. J Neurosci 2010; 30: 11858-69.

39 Pan Z, Kao T, Horvath Z, Lemos J, Sul JY, Cranstoun SD, et al. A common ankyrin-G-based mechanism retains $K C N Q$ and $N a V$ channels at electrically active domains of the axon. J Neurosci 2006; 26: 2599-613.

40 Ogawa Y, Horresh I, Trimmer JS, Bredt DS, Peles E, Rasband MN. Postsynaptic density-93 clusters Kv1 channels at axon initial segments independently of Caspr2. J Neurosci 2008; 28: 5731-9.

41 Rasband MN, Trimmer JS, Schwarz TL, Levinson SR, Ellisman MH, Schachner M, et al. Potassium channel distribution, clustering, and function in remyelinating rat axons. J Neurosci 1998; 18: 36-47.

42 Lorincz A, Nusser Z. Cell-type-dependent molecular composition of the axon initial segment. J Neurosci 2008; 28: 14329-40.

43 Shu Y, Yu Y, Yang J, McCormick DA. Selective control of cortical axonal spikes by a slowly inactivating $\mathrm{K}^{+}$current. Proc Natl Acad Sci U S A 2007; 104: 11453-8.

44 Kole MH, Letzkus JJ, Stuart GJ. Axon initial segment Kv1 channels control axonal action potential waveform and synaptic efficacy. Neuron 2007; 55: 633-47.

45 Alle H, Geiger JR. Combined analog and action potential coding in hippocampal mossy fibers. Science 2006; 311: 1290-3.

46 Shu Y, Hasenstaub A, Duque A, Yu Y, McCormick DA. Modulation of intracortical synaptic potentials by presynaptic somatic membrane potential. Nature 2006; 441: 761-5.

47 Johnston J, Griffin SJ, Baker C, Skrzypiec A, Chernova T, Forsythe ID. Initial segment Kv2.2 channels mediate a slow delayed rectifier and maintain high frequency action potential firing in medial nucleus of the trapezoid body neurons. J Physiol 2008; 586: 3493-509.

48 Cox DH, Cui J, Aldrich RW. Allosteric gating of a large conductance Ca-activated $\mathrm{K}^{+}$channel. J Gen Physiol 1997; 110: 257-81.

49 Fleidervish IA, Lasser-Ross N, Gutnick MJ, Ross WN. $\mathrm{Na}^{+}$imaging reveals little difference in action potential-evoked $\mathrm{Na}^{+}$influx between axon and soma. Nat Neurosci 2010; 13: 852-60.

50 Hallermann S, de Kock CPJ, Stuart GJ, Kole MHP. State and location dependence of action potential metabolic cost in cortical pyramidal neurons. Nat Neurosci 2012; 15: 1007-14.

51 Hu W, Tian C, Li T, Yang M, Hou H, Shu Y. Distinct contributions of $\mathrm{Na}(\mathrm{v}) 1.6$ and $\mathrm{Na}(\mathrm{v}) 1.2$ in action potential initiation and backpropagation. Nat Neurosci 2009; 12: 996-1002.

$52 \mathrm{Hu} \mathrm{H}$, Jonas P. A supercritical density of $\mathrm{Na}^{+}$channels ensures fast signaling in GABAergic interneuron axons. Nat Neurosci 2014; 17: 686-93.

53 Leterrier C, Brachet A, Dargent B, Vacher H. Determinants of voltagegated sodium channel clustering in neurons. Semin Cell Dev Biol 2011; 22: 171-7.

54 Fache MP, Moussif A, Fernandes F, Giraud P, Garrido JJ, Dargent B. Endocytotic elimination and domain-selective tethering constitute a potential mechanism of protein segregation at the axonal initial segment. J Cell Biol 2004; 166: 571-8.

55 Bréchet A, Fache MP, Brachet A, Ferracci G, Baude A, Irondelle M, et al. Protein kinase CK2 contributes to the organization of sodium channels in axonal membranes by regulating their interactions with ankyrin G. J Cell Biol 2008; 183: 1101-14.

56 Catterall WA. Voltage-gated sodium channels at 60: structure, function and pathophysiology. J Physiol 2012; 590: 2577-89.

57 Catterall WA, Goldin AL, Waxman SG. International Union of Pharmacology. XLVII. Nomenclature and structure-function relationships of voltage-gated sodium channels. Pharmacol Rev 2005; 57: 397-409.

58 Nusser Z. Differential subcellular distribution of ion channels and the diversity of neuronal function. Curr Opin Neurobiol 2012; 22: 366-71.

59 Lorincz A, Nusser Z. Molecular identity of dendritic voltage-gated sodium channels. Science 2010; 328: 906-9.

60 Li T, Tian C, Scalmani P, Frassoni C, Mantegazza M, Wang Y, et al. Action potential initiation in neocortical inhibitory interneurons. PLoS Biol 2014; 12: e1001944.

61 Van Wart A, Trimmer JS, Matthews G. Polarized distribution of ion channels within microdomains of the axon initial segment. J Comp Neurol 2007; 500: 339-52.

62 Duflocq A, Le Bras B, Bullier E, Couraud F, Davenne M. Nav1.1 is predominantly expressed in nodes of Ranvier and axon initial segments. Mol Cell Neurosci 2008; 39: 180-92.

63 Catterall WA, Kalume F, Oakley JC. NaV1.1 channels and epilepsy. J Physiol 2010; 588: 1849-59.

64 Tian C, Wang K, Ke W, Guo H, Shu Y. Molecular identity of axonal sodium channels in human cortical pyramidal cells. Front Cell Neurosci 2014; 8: 297.

65 Astman N, Gutnick MJ, Fleidervish IA. Persistent sodium current in layer 5 neocortical neurons is primarily generated in the proximal axon. J Neurosci 2006; 26: 3465-73.

66 Stuart G, Sakmann B. Amplification of EPSPs by axosomatic sodium channels in neocortical pyramidal neurons. Neuron 1995; 15 : 1065-76.

67 Astman N, Gutnick MJ, Fleidervish IA. Activation of protein kinase C increases neuronal excitability by regulating persistent $\mathrm{Na}^{+}$current in mouse neocortical slices. J Neurophysiol 1998; 80: 1547-51.

68 Kole MH. First node of Ranvier facilitates high-frequency burst encoding. Neuron 2011; 71: 671-82.

69 Lewis AH, Raman IM. Resurgent current of voltage-gated $\mathrm{Na}^{+}$ channels. J Physiol 2014; 592: 4825-38.

70 Kuba $\mathrm{H}$, Oichi $\mathrm{Y}$, Ohmori $\mathrm{H}$. Presynaptic activity regulates $\mathrm{Na}^{+}$ channel distribution at the axon initial segment. Nature 2010; 465: 1075-8.

71 Narayanan R, Johnston D. Long-term potentiation in rat hippocampal neurons is accompanied by spatially widespread changes in intrinsic oscillatory dynamics and excitability. Neuron 2007; 56: 1061-75.

72 Evans MD, Sammons RP, Lebron S, Dumitrescu AS, Watkins TB, Uebele VN, et al. Calcineurin signaling mediates activity-dependent relocation of the axon initial segment. J Neurosci 2013; 33: 695063. 
73 Buffington SA, Rasband MN. The axon initial segment in nervous system disease and injury. Eur J Neurosci 2011; 34: 1609-19.

74 Spira ME, Oren R, Dormann A, Ilouz N, Lev S. Calcium, protease activation, and cytoskeleton remodeling underlie growth cone formation and neuronal regeneration. Cell Mol Neurobiol 2001; 21 : 591-604.

75 von Reyn CR, Spaethling JM, Mesfin MN, Ma M, Neumar RW, Smith $\mathrm{DH}$, et al. Calpain mediates proteolysis of the voltage-gated sodium channel alpha-subunit. J Neurosci 2009; 29: 10350-6.

76 Iwata A, Stys PK, Wolf JA, Chen XH, Taylor AG, Meaney DF, et al. Traumatic axonal injury induces proteolytic cleavage of the voltagegated sodium channels modulated by tetrodotoxin and protease inhibitors. J Neurosci 2004; 24: 4605-13.

77 Hinman JD, Rasband MN, Carmichael ST. Remodeling of the axon initial segment after focal cortical and white matter stroke. Stroke 2013; 44: 182-9.

78 Bevers MB, Ingleton LP, Che D, Cole JT, Li L, Da T, et al. RNAi targeting micro-calpain increases neuron survival and preserves hippocampal function after global brain ischemia. Exp Neurol 2010; 224: $170-7$.

79 Goll DE, Thompson VF, Li H, Wei W, Cong J. The calpain system. Physiol Rev 2003; 83: 731-801.

80 Ma M. Role of calpains in the injury-induced dysfunction and degeneration of the mammalian axon. Neurobiol Dis 2013; 60: 61-79.

81 Fleidervish IA, Gebhardt C, Astman N, Gutnick MJ, Heinemann $U$. Enhanced spontaneous transmitter release is the earliest consequence of neocortical hypoxia that can explain the disruption of normal circuit function. J Neurosci 2001; 21: 4600-8.

82 Somjen GG. Mechanisms of spreading depression and hypoxic spreading depression-like depolarization. Physiol Rev 2001; 81: 1065-96.

83 Yu SP, Yeh C, Strasser U, Tian M, Choi DW. NMDA receptor-mediated K+ efflux and neuronal apoptosis. Science 1999; 284: 336-9.

84 Rossi DJ, Oshima T, Attwell D. Glutamate release in severe brain ischaemia is mainly by reversed uptake. Nature 2000; 403: 316-21.

85 Jonas $\mathrm{P}$, Burnashev N. Molecular mechanisms controlling calcium entry through AMPA-type glutamate receptor channels. Neuron 1995; 15: 987-90.

86 Gorter JA, Petrozzino JJ, Aronica EM, Rosenbaum DM, Opitz T, Bennett MV, et al. Global ischemia induces downregulation of Glur2 mRNA and increases AMPA receptor-mediated $\mathrm{Ca}^{2+}$ influx in hippocampal CA1 neurons of gerbil. J Neurosci 1997; 17: 6179-88.

87 Aarts M, lihara K, Wei WL, Xiong ZG, Arundine M, Cerwinski W, et al. A key role for TRPM7 channels in anoxic neuronal death. Cell 2003; 115: 863-77.

88 Szydlowska K, Tymianski M. Calcium, ischemia and excitotoxicity. Cell Calcium 2010; 47: 122-9.

89 Aarts MM, Tymianski M. TRPMs and neuronal cell death. Pflugers Arch 2005; 451: 243-9.

90 Harteneck C. Function and pharmacology of TRPM cation channels.
Naunyn Schmiedebergs Arch Pharmacol 2005; 371: 307-14.

91 Sun HS, Jackson MF, Martin LJ, Jansen K, Teves L, Cui H, et al. Suppression of hippocampal TRPM7 protein prevents delayed neuronal death in brain ischemia. Nat Neurosci 2009; 12: 1300-7.

92 Thompson RJ. Pannexin channels and ischaemia. J Physiol 2015; 593: 3463-70.

93 Sosinsky GE, Boassa D, Dermietzel R, Duffy HS, Laird DW, MacVicar $B$, et al. Pannexin channels are not gap junction hemichannels. Channels (Austin) 2011; 5: 193-7.

94 Thompson RJ, Zhou N, MacVicar BA. Ischemia opens neuronal gap junction hemichannels. Science 2006; 312: 924-7.

95 Zhang L, Deng T, Sun Y, Liu K, Yang Y, Zheng X. Role for nitric oxide in permeability of hippocampal neuronal hemichannels during oxygen glucose deprivation. J Neurosci Res 2008; 86: 2281-91.

96 Weilinger NL, Tang PL, Thompson RJ. Anoxia-induced NMDA receptor activation opens pannexin channels via Src family kinases. J Neurosci 2012; 32: 12579-88.

97 Bargiotas P, Krenz A, Hormuzdi SG, Ridder DA, Herb A, Barakat W, et al. Pannexins in ischemia-induced neurodegeneration. Proc Natl Acad Sci U S A 2011; 108: 20772-7.

98 Madry C, Haglerod C, Attwell D. The role of pannexin hemichannels in the anoxic depolarization of hippocampal pyramidal cells. Brain 2010; 133: 3755-63.

99 Wirkner K, Kofalvi A, Fischer W, Gunther A, Franke H, Groger-Arndt $\mathrm{H}$, et al. Supersensitivity of $\mathrm{P} 2 \mathrm{X}$ receptors in cerebrocortical cell cultures after in vitro ischemia. J Neurochem 2005; 95: 1421-37.

100 Weilinger NL, Maslieieva V, Bialecki J, Sridharan SS, Tang PL, Thompson RJ. Ionotropic receptors and ion channels in ischemic neuronal death and dysfunction. Acta Pharmacol Sin 2013; 34: 39-48.

101 Le Feuvre RA, Brough D, Touzani O, Rothwell NJ. Role of P2X7 receptors in ischemic and excitotoxic brain injury in vivo. J Cereb Blood Flow Metab 2003; 23: 381-4.

102 Del Puerto A, Fronzaroli-Molinieres L, Perez-Alvarez MJ, Giraud P, Carlier E, Wandosell F, et al. ATP-P2X7 receptor modulates axon initial segment composition and function in physiological conditions and brain injury. Cereb Cortex 2015; 25: 2282-94.

103 Hinzman JM, Andaluz N, Shutter LA, Okonkwo DO, Pahl C, Strong AJ, et al. Inverse neurovascular coupling to cortical spreading depolarizations in severe brain trauma. Brain 2014; 137: 2960-72.

104 Schoknecht K, Prager O, Vazana U, Kamintsky L, Harhausen D, Zille $\mathrm{M}$, et al. Monitoring stroke progression: in vivo imaging of cortical perfusion, blood-brain barrier permeability and cellular damage in the rat photothrombosis model. J Cereb Blood Flow Metab 2014; 34: 1791-801.

105 Hinman JD. The back and forth of axonal injury and repair after stroke. Curr Opin Neurol 2014; 27: 615-23.

106 von Bornstadt D, Houben T, Seidel JL, Zheng Y, Dilekoz E, Qin T, et al. Supply-demand mismatch transients in susceptible peri-infarct hot zones explain the origins of spreading injury depolarizations. Neuron 2015; 85: 1117-31. 